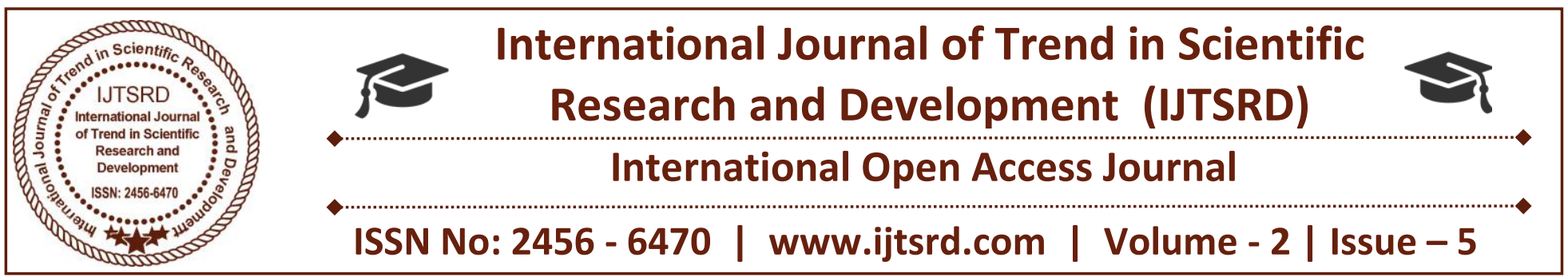

\title{
A Critical Analysis of Banana Cultivation in Thoothukudi District of Tamil Nadu
}

\author{
N. Amaladeepan ${ }^{1}$, J. Pushpa ${ }^{2}$ \\ ${ }^{1}$ M.Sc. , (Ag.) Student [Extension Education], ${ }^{2}$ Professor \& Head \\ Department of Social Sciences, Agricultural College and Research Institute, Killikulam, Vallanadu, \\ Tamil Nadu Agricultural University, Tamil Nadu, India
}

\section{ABSTRACT}

Banana is a very popular fruit due to its low price and high nutritive value. The study was conducted at Thoothukudi district of Tamil Nadu. Two blocks in Thoothukudi were selected for this study and 120 respondents were selected from two villages in each block by proportionate random sampling method to assess the extent of knowledge and adoption of banana cultivation technologies by banana growers and also 40 banana growing farmers who adopted drip-irrigation system were selected as purposively for assessing the performance of drip-irrigation in banana cultivation. The study here explored the extent of knowledge and adoption level of banana growers and performance of drip-irrigation in banana cultivation. With respect to knowledge and adoption level of banana growers, majority of the respondents 54.17 per cent had high level of knowledge on banana cultivation technologies and 87.50 per cent had medium to high level of adoption of banana cultivation technologies. With regard to the performance of drip-irrigation in banana cultivation, the benefits as perceived by the drip adopted banana growers were reduced weed growth, less labour requirement for irrigation, weed management, fertilizer application and also increases the water use efficiency. These studies also suggested that necessary follow up help should be given to the drip adopted banana growers after installation by the company and impart trainings to banana growers on maintenance of drip-irrigation equipment.

Keywords: Banana cultivation, Knowledge, Adoption and Drip-irrigation

\section{INTRODUCTION}

Banana is a very popular fruit due to its low price and high nutritive value. Bananas are predominantly produced in Asia, Latin America and Africa. India is the biggest producers of banana. Globally, banana production had reached a record of 117.9 million tonnes in 2015 as compared to 2000. In India, banana is an important fruit crop grown next to mango. The area under banana was 8.03 lakh hectares in 2013-14 and the production was 29.7 Metric tonnes with the productivity of about 7.00 Metric per Hectare in 2013-14. In India, the major banana growing states are Tamil Nadu as followed by Karnataka and Andhra Pradesh (Indian Horticulture Database, 2015). Banana being a succulent, evergreen and shallow rooted crop requires large quantity of water of increasing productivity. Water requirement of banana has been worked out to be $1800-2000 \mathrm{~mm}$ per annum. In spite of having the largest Irrigated area in the world, India also started facing severe water scarcity in different region (Saleth, 1996). Micro Irrigation is introduced primarily to save water and increase the water use efficiency in agriculture. It was concluded that drip irrigation is viable and more beneficial in region where there is more water scarcity. By using the drip the water use efficiency was higher and the system saved 50.00 per cent of irrigation water (B. Cevik, 1988).

\section{Objectives}

1. To assess the extent of knowledge and adoption of banana cultivation technologies by banana growers.

2. To study the performance of drip irrigation in banana cultivation and constraints faced by them. 


\section{Methodology}

This study was conducted in Thoothukudi district of Tamil Nadu. In Thoothukudi district, two blocks viz., Srivaikundam and Alwarthirunagiri were selected where the area under banana cultivation is predominant. Two villages were selected randomly from each block. From these selected four villages, 120 farmers growing banana were selected by applying proportionate random sampling method to assess the extent of knowledge and adoption of banana cultivation technologies by banana growers and also 40 banana growing farmers who adopted drip irrigation were selected as purposively for assessing the performance of drip-irrigation in banana cultivation. A well-structured interview schedule was prepared to conduct survey. The extent of knowledge and adoption of banana cultivation technologies by banana growers were assessed with the help 32 questions related to crop production technologies, crop protection technologies and harvest technology. The performance of drip-irrigation was assessed by five parameters which were selected in consultation with concerned scientist and extension personnel in the field. The respondents were asked to indicate the constraints in the drip irrigation faced by them under banana cultivation.

\section{Findings and Discussion}

Knowledge and Adoption of banana cultivation technologies

\section{Table 1.Distribution of respondents according to their overall knowledge and adoption on banana cultivation technologies}

\begin{tabular}{|c|c|c|c|c|c|}
\hline \multicolumn{2}{|c|}{$\begin{array}{c}\text { S. } \\
\text { No }\end{array}$} & Category & \multicolumn{2}{|c|}{ Knowledge } & \multicolumn{2}{c|}{\begin{tabular}{c} 
Adoption \\
\cline { 3 - 6 }
\end{tabular}} & $\begin{array}{c}\text { Num } \\
\text { ber }\end{array}$ & $\begin{array}{c}\text { Per } \\
\text { cent }\end{array}$ & $\begin{array}{c}\text { Numb } \\
\text { er }\end{array}$ & $\begin{array}{c}\text { Per } \\
\text { cent }\end{array}$ \\
\hline 1. & Low & 8 & 6.67 & 15 & 12.50 \\
\hline 2. & Medium & 47 & 39.17 & 58 & 48.33 \\
\hline 3. & High & 65 & 54.17 & 47 & 39.17 \\
\hline & Total & 120 & 100.00 & 120 & 100.00 \\
\hline
\end{tabular}

It is revealed from Table 1 . that majority of the respondents $(54.17 \%)$ had high level of knowledge followed by 39.17 per cent of the respondents had medium level of knowledge and the remaining 6.67 per cent of the respondents had low level of knowledge on banana cultivation technologies. Majority of the respondents $(87.5 \%)$ had medium to high level of adoption and the remaining 12.5 per cent of the respondents adopted banana cultivation technologies in low level.

Table 2.Technolgy- wise knowledge and adoption level of respondents on banana cultivation practices

\begin{tabular}{|c|l|c|c|c|c|}
\hline \multicolumn{2}{|c|}{ Practices } & \multicolumn{2}{c}{ Knowledge } & \multicolumn{2}{c|}{ Adoption } \\
\cline { 3 - 6 } S. & & Number & Percent & Number & Percent \\
\hline N. & Crop production technologies & & & & \\
\hline 1. & Season for banana cultivation & 120 & 100.00 & 120 & 100.00 \\
\hline 2. & Varieties suited & 120 & 100.00 & 120 & 100.00 \\
\hline 3. & Selection of planting Material (sucker) & 119 & 99.17 & 118 & 98.33 \\
\hline 4. & Preparation of main field for banana cultivation & 117 & 97.50 & 94 & 78.33 \\
\hline & Pre-treatment of sucker & & & & \\
\hline 5. & Pre-treatment practices of sucker & 111 & 92.50 & 26 & 21.67 \\
\hline 6. & Chemical used for pre-treatment of sucker with dosage & 41 & 34.17 & 24 & 20.00 \\
\hline & Sucker planting & & & & \\
\hline 7. & Spacing used for banana & 119 & 99.17 & 119 & 99.17 \\
\hline 8. & Methods of planting the sucker & 120 & 100.00 & 120 & 100.00 \\
\hline & Irrigation Management & & & & \\
\hline 9. & Life irrigation practices & 108 & 90.00 & 72 & 60.00 \\
\hline 10. & Gap between the subsequent irrigation & 118 & 98.33 & 109 & 90.83 \\
\hline & Nutrient Management & 120 & & & \\
\hline 11. & Recommended quantity of N:P:K/plant/yr & 79 & 65.83 & 103 & 85.83 \\
\hline 12. & Recommended Micro-Nutrient & & & & 44.17 \\
\hline & Intercultural Operations & & & & \\
\hline
\end{tabular}




\begin{tabular}{|c|c|c|c|c|c|}
\hline \multirow{2}{*}{$\begin{array}{l}\text { S. } \\
\text { No. }\end{array}$} & \multirow[t]{2}{*}{ Practices } & \multicolumn{2}{|c|}{ Knowledge } & \multicolumn{2}{|c|}{ Adoption } \\
\hline & & Number & Percent & Number & Percent \\
\hline 13. & Desuckering & 120 & 100.00 & 120 & 100.00 \\
\hline 14. & Propping & 119 & 99.17 & 113 & 94.17 \\
\hline 15. & Earthing up & 120 & 100.00 & 119 & 99.17 \\
\hline 16. & Denavelling & 120 & 100.00 & 119 & 99.17 \\
\hline 17. & Peduncle Wrapping & 105 & 87.50 & 78 & 65.00 \\
\hline 18. & Wind Break & 58 & 48.33 & 48 & 40.00 \\
\hline 19. & Mulching & 78 & 65.00 & 71 & 59.17 \\
\hline \multirow[t]{2}{*}{20.} & Pruning of Leaves & 105 & 87.50 & 84 & 70.00 \\
\hline & Weed Management & & & & \\
\hline 21. & Recommended Herbicide & 115 & 95.83 & 39 & 32.50 \\
\hline 22. & Hand weeding & 118 & 98.33 & 104 & 86.67 \\
\hline 23. & Inter-cropping practices & 78 & 65.00 & 11 & 9.17 \\
\hline \multirow[t]{2}{*}{ II. } & Crop protection technologies & + & & & \\
\hline & Pest management & 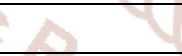 & & & \\
\hline 24. & Banana aphid & 71 & 59.17 & 56 & 46.67 \\
\hline 25. & Pseudostem borer & 110 & 91.67 & 93 & 77.50 \\
\hline \multirow[t]{2}{*}{26.} & Rhizome weevil & 107 & 89.17 & 92 & 76.67 \\
\hline & Disease management & +2 & & & \\
\hline 27. & Panama Disease (Fusarium wilt) & 1110 & 92.50 & 97 & 80.83 \\
\hline 28. & Freckle leaf spot & 107 & 89.17 & 97 & 80.83 \\
\hline \multirow[t]{2}{*}{29.} & Bunchy-top $\quad$ of Trend in Scier & 68 & 56.67 & 58 & 48.33 \\
\hline & Nematode management & & 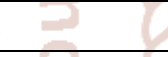 & & \\
\hline 30. & Burrowing nematode & 106 & 88.33 & 51 & 42.50 \\
\hline III. & Harvest $\quad=$ & + & 0 & & \\
\hline 31. & Harvesting period & 120 & 100.00 & 119 & 99.17 \\
\hline 32. & Maturity indices of banana & 118 & 98.33 & 118 & 98.33 \\
\hline
\end{tabular}

\section{Crop Production:}

\section{Season and Variety}

There are two season for banana cultivation i.e., Maasipattam (Feb.-April) and Chithiraipattam (April -May) were practised traditionally in Thoothukudi district. In banana the varieties recommended for Maasipattam in Thoothukudi district are Kadhali, Rasthali, Rasa kadhali, Monthan and Karpooravalli. The varieties recommended for Chithiraipattam in Thoothukudi district are Nendran and Robust.

With respect to adoption, it is evident from the Table 2 that the respondents in the study area raised the crop during both Maasipattam (Kadhali) and Chithiraipattam (Nendran). Also it could be observed that some of the respondents were cultivated both the Kadhali and Nendran variety and some of the respondents cultivated any one among the above mentioned varieties only.

\section{Field Preparation and Sucker Selection}

Majority of the respondents $(97.05 \%)$ had acquired knowledge on preparation of main field for banana cultivation by forming beds and furrows in the field and 99.17 per cent of the respondents had knowledge on selection of quality sucker (sword suckers of 1.5 to $2.0 \mathrm{~kg}$ weight).

With respect to extent of adoption of recommended technologies, majority of the respondents $(78.33 \%)$ adopted the crop production technologies like field preparation by forming beds and furrows and recommended selection procedure for planting material $(98.33 \%)$. The reason might be due to the fact that these technologies were adopted traditionally over a period of time.

Pre-treatment and Planting of Sucker 
It could be observed that more than three fourth of the respondents $(92.50 \%)$ had knowledge on pre-

treatment of sucker and only 34.17 per cent of the respondents had knowledge on the chemical used for sucker treatment. Further, it was observed that majority of the respondents $(99.17 \%)$ had knowledge on the recommended spacing and mostly all the respondents were had knowledge on method of planting the sucker.

With respect to extent of adoption, only few respondents $(21.67 \%)$ and 20.00 per cent had adopted the pre-treatment of sucker and the chemical used for sucker treatment. More than four fifth of the respondents $(99.17 \%)$ adopted the recommended spacing and cent per cent of the respondents adopted the pit method of planting.

\section{Irrigation Management}

With respect to Irrigation management, it is concluded that more than four fifth of the respondents $(90.00 \%)$ and 98.33 per cent had knowledge on life irrigation technologies and gap between the subsequent irrigation for banana cultivation

With respect to extent of adoption in irrigation management, more than half of the respondents $(60.00 \%)$ had adopted the recommended life irrigation technologies and 90.83 per cent of the respondents adopted the correct gap between subsequent irrigation since there is water scarcity.

\section{Nutrient Management}

In consideration with nutrient management, all respondent had well versed knowledge level in recommended N: P: K fertilizer dosage for banana cultivation and more than half of the respondents (65.83 \%) had knowledge on Micro-Nutrient with recommended dosage.

With respect to extent of adoption level for recommended fertilizers application, it is revealed that 85.83 per cent and 44.17 per cent of the respondents had adopted the recommended level of $\mathrm{N}$ : P: K fertilizer and Micro-Nutrient application respectively.

\section{Intercultural Operations}

With respect to the Intercultural Operation, it could be observed that all the respondents in the study area had knowledge on desuckering, earthingup and denavelling techniques. Most of the respondents
(99.17 \%) had knowledge on propping techniques then 87.50 per cent of the respondents had knowledge on both peduncles wrapping and pruning of leaves techniques. Only more than half of the respondents $(65.00 \%)$ had knowledge on mulching the field and 48.33 per cent of the respondents had knowledge on wind break on their field.

With respect to the extent of adoption of Intercultural Operation, cent per cent of the respondents had adopted desuckering, 99.17 per cent of the respondents adopted earthingup and denavelling technologies, nearly 94.17 per cent of the respondents were adopting propping technologies. Then 70.00 per cent, 65.00 per cent and 59.17 per cent of the respondents were adopting pruning of leaves, peduncle wrapping and mulching as respectively. Only 40.00 per cent of the respondents had grown casuarina tree sp. as wind break in their field.

\section{Weed Management}

With respect to weed management most of the respondents $(98.33 \%)$ had knowledge on hand weeding and 95.83 per cent of the respondents had knowledge on herbicide to control weed. Only more than half of the respondents $(65.00 \%)$ had knowledge inter-cropping to control weeds.

With respect to the extent of adoption of weed management, more than three fourth of the respondents $(86.67 \%)$ were adopting hand weeding and more than one fourth of the respondents $(32.50$ $\%$ ) adopted recommended herbicide to control weeds in the field. Only 9.17 per cent of the respondents were adopting inter cropping technologies to control weed growth.

\section{Crop Protection Technologies: Pest Management}

In the study area, the pest such as pseudo stem borer, rhizome weevil and banana aphid were the major pest found in banana cultivation. This might be the reason for higher percentage of respondents acquired knowledge as 91.67 per cent, 89.17 per cent and 59.17 per cent on the pest pseudo stem borer, rhizome weevil and banana aphid respectively.

With respect to extent of adoption, more than three fourth of the respondents $(77.50 \%)$ and $(76.67 \%)$ were adopted the recommended management technologies for pseudo stem borer and rhizome weevil. Only 46.67 per cent of the respondents followed the recommended management technologies to control banana aphid. 


\section{Disease Management}

In the study area, the disease such as panama disease, freckle leaf spot and bunchy top disease were the major disease found in banana cultivation. This might be the reason for higher percentage of respondents acquired knowledge as 92.50 per cent, 89.17 per cent and 56.67 per cent on the diseases panama disease, freckle leaf spot and bunchy top respectively.

With respect to extent of adoption, more than three fourth of the respondents $(80.83 \%)$ were adopting the management technologies for both the freckle leaf spot and panama disease. only 48.33 per cent of the respondents had adopted the recommended management technologies for bunch top diseases.

\section{Nematode Management}

With respect to nematode management, more than three fourth of the respondents $(88.33 \%)$ had well knowledge on management technologies for burrowing nematodes.

While considering the extent of adoption of nematode management, more than two fifth of the respondents $(42.50 \%)$ had adopted the management technologies for controlling the burrowing nematodes.

\section{Harvest}

With respect to harvesting, cent per cent of the respondents had knowledge about the harvesting period and 98.33 per cent of the respondents had knowledge on the maturity indices of banana to harvest. This might be due to their experiences in banana cultivation.

While considering the extent of adoption, majority of the respondents 99.17 per cent were harvesting their fruit at the right time (90 to 150 days after shooting) and 98.33 per cent of the respondents harvested the matured fruit at optimum stage when the colour of the bunch changes from deep green to light yellow.

\section{Table 3.Correlation of characteristics of banana growers with their knowledge}

$(n=120)$

\begin{tabular}{clc} 
S. & \multicolumn{1}{c}{ Variables } & $\begin{array}{c}\text { Correlation } \\
\text { value }\end{array}$ \\
No & Age & $-0.081^{\text {NS }}$ \\
X2 & Educational status & $0.630^{* *}$ \\
X3 & Occupational status & $0.050^{\mathrm{NS}}$ \\
X4 & Family type & $-0.001^{\mathrm{NS}}$ \\
X5 & Farm size & $0.257^{* *}$ \\
X6 & Area under Banana & $0.247^{* *}$
\end{tabular}
$\mathrm{X} 7 \quad$ Experience
$-0.041^{\mathrm{NS}}$
$\mathrm{X} 8$
Information
Seeking
$0.638^{* *}$
Behaviour
X9 Social participation
$0.055^{\mathrm{NS}}$

\begin{tabular}{|r|l|c|}
\hline $\begin{array}{r}\text { S. } \\
\text { No }\end{array}$ & \multicolumn{1}{|c|}{ Variables } & $\begin{array}{c}\text { Correlation } \\
\text { value }\end{array}$ \\
\hline X10 & Innovativeness & $0.596^{* *}$ \\
\hline X11 & Scientific Orientation & $0.646^{* *}$ \\
\hline X12 & Risk Orientation & $0.465^{* *}$ \\
\hline X13 & Progressiveness & $0.548^{* *}$ \\
\hline X14 & Credit Orientation & $0.169^{\mathrm{NS}}$ \\
\hline X15 & Economic Motivation & $-0.043^{\mathrm{NS}}$ \\
\hline X16 & Annual income & $0.225^{*}$ \\
\hline
\end{tabular}

** Significant at 1 per cent level

* $\quad$ Significant at 5 per cent level

NS Non- Significant

\section{Simple correlation analysis}

From the above Table 3, it is revealed that eight variables viz., educational status $\left(\mathrm{X}_{2}\right)$, farm $\operatorname{size}\left(\mathrm{X}_{5}\right)$, area cunder 2 banana $\left(\mathrm{X}_{6}\right)$, information seeking behaviour $\left(\mathrm{X}_{8}\right), \quad$ innovativeness $\left(\mathrm{X}_{10}\right), \quad$ scientific orientation $\left(\mathrm{X}_{11}\right)$, risk orientation $\left(\mathrm{X}_{12}\right)$ and progressiveness $\left(\mathrm{X}_{13}\right)$ showed positive and significant relationship with knowledge $\left(\mathrm{Y}_{1}\right)$ at one per cent level of significant. Only one variable annual income $\left(\mathrm{X}_{16}\right)$ showed positive and significant relationship with knowledge $\left(\mathrm{Y}_{1}\right)$ at five per cent level of significant. Then the other variables are showed non-significant relation with knowledge.

In general, the more the educational status, farm size, area under banana, information seeking behaviour, innovativeness, scientific orientation, risk orientation, progressiveness and annual income the more will be the chances for knowing and understanding the technologies and hence the variables showed positive and significant relationship.

\section{Table 4.Correlation of characteristics of banana growers with their adoption}

$(\mathbf{n}=120)$

\begin{tabular}{|c|l|c|}
\hline $\begin{array}{r}\text { S. } \\
\text { No }\end{array}$ & \multicolumn{1}{|c|}{ Variables } & $\begin{array}{c}\text { Correlation } \\
\text { value }\end{array}$ \\
\hline X1 & Age & $-0.132^{\text {NS }}$ \\
\hline X2 & Educational status & $0.662^{* *}$ \\
\hline X3 & Occupational status & $-0.011^{\mathrm{NS}}$ \\
\hline X4 & Family type & $-0.011^{\mathrm{NS}}$ \\
\hline X5 & Farm size & $0.256^{* *}$ \\
\hline
\end{tabular}


International Journal of Trend in Scientific Research and Development (IJTSRD) ISSN: 2456-6470

\begin{tabular}{|l|l|c|}
\hline X6 & Area under Banana & $0.247^{* *}$ \\
\hline X7 & Experience & $-0.194^{*}$ \\
\hline X8 & $\begin{array}{l}\text { Information Seeking } \\
\text { Behaviour }\end{array}$ & $0.612^{* *}$ \\
\hline
\end{tabular}

positive and significant association with adoption $\left(\mathrm{Y}_{2}\right)$ at five per cent level of significance. Only one variable experience $\left(\mathrm{X}_{7}\right)$ had show negative and significant association with adoption $\left(\mathrm{Y}_{2}\right)$ at five per cent level of significance. Then the other variables are showed non-significant relation with adoption.

\begin{tabular}{|l|l|c|}
\hline $\begin{array}{c}\text { S. } \\
\text { No }\end{array}$ & \multicolumn{1}{|c|}{ Variables } & $\begin{array}{c}\text { Correlation } \\
\text { value }\end{array}$ \\
\hline X9 & Social participation & $0.005^{\text {NS }}$ \\
\hline X10 & Innovativeness & $0.544^{* *}$ \\
\hline X11 & Scientific Orientation & $0.598^{* *}$ \\
\hline X12 & Risk Orientation & $0.462^{* *}$ \\
\hline X13 & Progressiveness & $0.510^{* *}$ \\
\hline X14 & Credit Orientation & $0.221^{*}$ \\
\hline X15 & Economic Motivation & $-0.113^{\text {NS }}$ \\
\hline X16 & Annual income & $0.192^{*}$ \\
\hline
\end{tabular}

** Significant at 1 per cent level

* Significant at 5 per cent level

NS Non- Significant

\section{Simple correlation analysis}

From the above Table 4, It could be observed that the eight variables educational status $\left(\mathrm{X}_{2}\right)$, farm size $\left(\mathrm{X}_{5}\right)$, area under banana $\left(\mathrm{X}_{6}\right)$, information - seeking behaviour $\left(\mathrm{X}_{8}\right)$, innovativeness $\left(\mathrm{X}_{10}\right)$, scientific orientation $\left(\mathrm{X}_{11}\right)$, risk orientation $\left(\mathrm{X}_{12}\right)$ and progressiveness $\left(\mathrm{X}_{13}\right)$ had shown positive and significant association with adoption $\left(\mathrm{Y}_{2}\right)$ at one per In general, more the educational status, farm size, area under banana, information seeking behaviour, innovativeness, scientific orientation, risk orientation, progressiveness, credit orientation and annual income the more would be the chances for accepting, understanding and adopting the technologies and that might be the reason for positive and significant association with adoption. If more the experiences of banana growers the less would be the chances for accepting the banana cultivation technologies and this might be due to the rigidness of not to change of traditional way of cultivation because of their age old experiences in banana cultivation

\section{Performance of Drip-irrigation in Banana \\ Cultivation}

The performance of drip-irrigation in banana cultivation was accessed by five parameters which were selected in consultation with concerned scientist and extension personnels in the field. The performance of banana cultivation in drip irrigation is presented below in Table 5 .

cent level of significance. Then two variables credit orientation $\left(\mathrm{X}_{14}\right)$ and annual income $\left(\mathrm{X}_{16}\right)$ had shown

Table 5.Performance of drip-irrigation in Banana Cultivation

\section{$(n=40)$}

\begin{tabular}{|c|c|c|c|c|}
\hline S. No & \multicolumn{2}{|r|}{ Particulars } & Number & Per cent \\
\hline \multirow[t]{4}{*}{ I. } & & Irrigation: & 20 & \\
\hline & 1. & Increasing the water use efficiency & 37 & 92.50 \\
\hline & 2. & Reducing the water losses & 35 & 87.50 \\
\hline & 3. & Less labour requirement for irrigation & 38 & 95.00 \\
\hline \multirow[t]{4}{*}{ II. } & \multicolumn{2}{|r|}{ Fertilizer application: } & & \\
\hline & 1. & Fertigation (Fertilizer + Irrigation) & 30 & 75.00 \\
\hline & 2. & Increased fertilizer efficiency & 29 & 72.50 \\
\hline & 3. & Less labour requirement for fertilizer application & 37 & 92.50 \\
\hline III. & \multicolumn{2}{|r|}{ Weed management } & & \\
\hline & 1. & Reduced weed growth & 39 & 97.50 \\
\hline & 2. & Less labour requirement for weed management & 38 & 95.00 \\
\hline \multirow[t]{3}{*}{ IV. } & \multicolumn{2}{|r|}{ Pest \& Disease Incidences: } & & \\
\hline & 1. & Low insect incidence & 33 & 82.50 \\
\hline & 2. & Low Disease incidence & 33 & 82.50 \\
\hline V. & \multicolumn{2}{|r|}{ Yield parameters: } & & \\
\hline & 1. & Increase in fruit yield & 23 & 57.50 \\
\hline & 2. & Increase in bunch weight & 26 & 65.00 \\
\hline
\end{tabular}


From the Table 5 the performances of drip-irrigation in banana cultivation were assessed in various aspects such as irrigation, fertilizer application, weed management, insect and disease incidences and yield parameters. It could be inferred that 92.50 per cent of the respondents reported that drip irrigation increased the water use efficiency followed by 87.50 per cent of the banana growers perceived that water losses reduced in banana cultivation. This might be due to the conventional bed based irrigation resulted in water losses and weed growth in the field.

Due to drip irrigation in banana cultivation, 72.50 per cent of the respondents perceived increased fertilizer efficiency followed by 92.00 and 95.00 per cent of them reported that less labour requirement for fertilizer application and to control of weed respectively. With respect to insect and disease incidence 82.50 per cent felt that reduction in insect and disease incidences due to maintenance of optimum irrigation management and control of plant growth due to drip irrigation.

With regard to yield parameter, majority of the respondents reported that there is increase in bunch weight and increase in fruit yield as compared to conventional method of irrigation in banana cultivation.

\section{Constraints as perceived by the Drip-irrigated} banana growers

The respondents were asked to indicate the constraints faced by them under drip irrigated banana cultivation. The constraints as perceived by the drip irrigated banana growers were presented below in the Table 6 .

\section{Table 6.Constraints as perceived by the drip- irrigated banana growers}

\begin{tabular}{|c|l|c|c|}
\hline S.No & \multicolumn{1}{|c|}{ Particulars } & Number & $\begin{array}{c}\text { Per } \\
\text { cent }\end{array}$ \\
\hline 1. & $\begin{array}{l}\text { Clogging problem in } \\
\text { emitter }\end{array}$ & 33 & 82.50 \\
\hline 2. & $\begin{array}{l}\text { Difficulty in inter- } \\
\text { cultural operations }\end{array}$ & 22 & 55.00 \\
\hline 3. & High initial cost & 21 & 52.50 \\
\hline 4. & Restricted root growth & 11 & 27.50 \\
\hline
\end{tabular}

It could be observed from Table 6 that the various constraints perceived by the drip-irrigated banana growers were clogging in the emitter by 82.50 per cent as followed by difficulty in inter-cultural operations by 55.0 per cent and high initial cost for setting up the drip irrigation system $(52.50 \%)$, root growth restriction also found to be one of the least constraints as perceived by 27.50 per cent of the farmers who adopted drip irrigation system.

\section{Conclusion}

It could be inferred from the study that majority of the respondents $(54.17 \%)$ had high level of knowledge on banana cultivation technologies and majority of the respondents $(87.5 \%)$ had medium to high level of adoption of banana cultivation technologies.

With respect to the performance of drip-irrigation in banana cultivation, major benefits as perceived by the respondents were reduced weed growth, less labour requirement for irrigation, weed management and fertilizer application. Further, it also increases the water use efficiency. Then the constraints in dripirrigation as perceived by the respondents were clogging in the emitter, difficult in inter-cultural operations and high initial cost while setting up the drip irrigation system in the field. Hence it is suggested that necessary follow up help should be given by the company after installation of dripirrigation system and also need to impart training to the farmers on maintenance of drip-irrigation equipment.

\section{References:}

1. B. Cevik, N. Kaska, O. Tekinel, M. Pekmezci, N. Yaylali, S. Paydas (1988) Comparison of drip and basin irrigation systems in banana orchards on the southern coast of turkey, ISHS Acta Horticulture 228: IV International Symposium on Water Supply and Irrigation in the Open and under Protected Cultivation, 10.17660/ActaHortic.1988.228.24

2. Indian Horticulture Database (2015), National Horticulture Board, Ministry of Agriculture, Government of India, 85, Institutional Area, Sector-18,Gurgaon-122 015 INDIA

3. Saleth, R. Maria. (1996), Water Institutions in India: Economics, Law and Policy, Commonwealth Publishers, New Delhi. 